\title{
Mitochondrial NADH Dehydrogenase gene (mtND2) Phylogeny of Egyptian Tilapia species
}

\author{
Mohammed H. Awwad \\ Department of Zoology, Faculty of Science, Zagazig University, Benha Branch
}

\begin{abstract}
NADH dehydrogenase is a very important protein and is expressed by the mitochondrial NADH dehydrogenase gene (mtND2). Dehydrogenase enzyme is used to remove hydrogen from its substrate, which is used in the cytochrome (hydrogen carrier) system in respiration to produce a net gain of ATP. Also, it reversibly catalyses the oxidation of NADH to NAD and reduced acceptor. The size of mtDN2 of Tilapia species and their hybrids is $\sim 1050$ base pairs and was detected by using the polymerase chain reaction technique. To identify the molecular phylogeny and the physical characteristics of mtND2 gene of Tilapia species were done by using the restriction fragment length polymorphisms (RFLPs) with some restriction endonucleases(AccI, AvaII, AvaI, StyI, BglI and EaeI). The PCR-RFLPs of NADH dehydrogenase gene of Tilapia species and their hybrids may prove that the gene is quite evolution phylogenetic difference from one species to another. At the same time, This study investigated the feasibility of mitochondrial DNA (mtDNA) based approaches in addressing problems of identification of Tilapia species and their hybrids, isolated from the River Nile by using the PCR-RFLPs analysis of mtND2 gene.
\end{abstract}

Key words; Tilapia spp., PCR-RFLP, mtND2, Polymorphism

\section{Introduction}

Tilapias are a group of 40-50 species of cichlid fish (genus Oreochromis, Sarotherodon and Tilapia) native to Africa, in particular Egypt. The significance of Tilapia for human culture predates their modern scientific investigation, e.g., Oreochromis niloticus, a geographically widespread Tilapia, was already known to the early Egyptian cultures and played a significant role in their lives, as indica -ted by their presence in ancient Egyptian art (Fryer and Iles, 1972). Tilapias continue to have great econo -mic importance because several species are an important source of protein in human diets, particularly in Egypt, and increasingly, through aquaculture, worldwide (Pullin and Lowe-Mc Connell, 1982 and Trewavas, 1982). Widespread exploitation and aquaculture of Tilapia has lead to their introduction in all tropical regions around the globe, often adversely affecting the natural ichthyofauna.

The first genetic linkage map of the O. niloticus linked 162 microsatellite and
AFLP markers (Kocher et al., 1998). The second generation map is based on an F2 cross between $O$. niloticus and $O$. aureus, and contains over 500 microsatellite markers (Danley and Kocher, 2001).

Tilapia fish have received wide attention from evolutionary biologists for more than 100 years because of their extremely diverse morphology, behavior, and ecology (Fryer and Iles, 1972; Liem and Osse, 1975; Greenwood, 1978; Trewavas, 1983; Oliver, 1984; Meyer et al., 1990; Keenleyside, 1991; Meyer, 1993; Meyer et al., 1994; Stiassny and Meyer, 1999).

Phylogenies for Tilapia genera were inserted at positions suggested by Sodsuk (1993) and Schliewen et al. (1994), and Sturmbauer et al. (1994), respectively. Previous research on Tilapia focused on all aspects of their biology, including behavior, ecology, and evolutionary biology (Keenleyside, 1991). The recently gathered knowledge of Tilapia spp. phylogenetic relation -ships (e.g., Oliver, 1984; Stiassny, 
1991; Kocher et al., 1993; Meyer, 1993; Zardoya et al., 1996; Kullander, 1998; Streelman et al., 1998 and Farias et al., 1999) has permitted the study of the evolution of their diverse ecology and varied mating and parental care behaviors (Goodwin et al., 1998). Until quite recently, the investigation of phylogenetic relationships among cichlids was restricted to morphological characteristics (Stiassny, 1991 and Kullander 1998). However, although Tilapias are a morphologically extrem -ely diverse group, there are only few morphological characteristics which can be used to examine the intrafamilial relationships (Stiassny, 1991).

The phylogenetic validity of the morphological criterion and the consequential subdivision of Tilapia fish have been repeatedly challenged during the last 80 years (Regan, 1920; 1922; Greenwood, 1978; Stiassny, 1991 and Kullander 1998). Even the Egyptian Tilapias are questioned by some modern scientists (Stiassny, 1991; Zardoya et al., 1996; Kullander, 1998 Streelman et al., 1998; Farias et al., 1999; 2000 and 2001).

Tilapias, by Stiassny's definition, are a more reduced grouping, as compared with the taxonomic entity characterized by Tilapia-type apophysis by Regan (1920) and corresponds well with the traditional view of the genus Tilapia. Tilapia was split by Trewavas into several genera, including Tilapia, Oreochromis, and Sarotherodon (Trewavas, 1983).

It is known that dehydrogenase enzyme is used to remove hydrogen from its substrate, which is used in the cytochrome (hydrogen carrier) system in respiration to produce a net gain of ATP. Also, it reversibly catalyses the oxidation of NADH (Nicotinamide Adenine Dinucleotide, reduced form to NAD (Nicotinamide Adenine Dinucleotide) and reduced acceptor.

The present study determined the DNA PCR-RFLPs of the mitochondrial NADH dehydrogenase subunit 2 (ND2) genes from a representative collection of some Egyptian Tilapia to further examine behavioral and morphological hypotheses concerning the evolution of the Tilapia spp. This gene was previously analyzed by
Kocher et al., (1995) in an effort to elucidate taxonomic relationships among the east African cichlids of Lakes Malawi and Tanganyika.

\section{Material And Methods Fish Collection:}

Live Tilapia fish were fished from El-Tawfiqi Stream (a branch of the Nile river) and carried to the laboratory in Faculty of Science- Zagazig UniversityBenha- Egypt. By using the morphometric analysis and the meristic analysis, the Tilapia spp. were arduously identified into T. zillii (Tilapia), O. niloticus and O. aureus (Oreochromis), S. galilaeus (Sarotherodon) and two hybrids ( $\mathrm{H} 1$ and $\mathrm{H} 2$; Azab, in press). The fish were killed and liver pieces were stored in the freezer until the DNA extraction started within one week.

\section{Total DNA content Extraction:}

Total DNA was extracted from the liver of the Tilapia species ( T. zillii, O. niloticus, $O$. aureus and S. galilaeus) and their hybrids using the UNSET lysis solution (Hugo et al., 1992 and El-Serafy et $a l$., in press). One $\mu \mathrm{l}$ of the total DNA content was checked by $0.8 \%$ gel electrophoresis for the presence of DNA, as in Figure 1.

Detection and Amplification of ND2 gene The mitochondrial NADH dehydrogenase (ND2) gene was PCR amplified using published primers in the flanking methionine ("ND2Met" 59-CATACCCC AAACATGTTGGT- 39, internal primer number 2, Kocher et al. 1995) and tryptophan ('ND2Trp"' 59- GTSGSTTTTCACT CCCGCTTA- 39, Kocher et al., 1995).

The standard polymerase chain reaction program for amplification of nuclear srRNA was: $30-35$ cycles; one minute, at $94^{\circ} \mathrm{C}$; two to three minutes, at $45^{\circ} \mathrm{C}$; and three minutes, at $72^{\circ} \mathrm{C}$ (El-Serafy et al., in press).

\section{Production and Evaluation of the} Mitochondrial ND2 gene RFLPs Profiles:

The enzymes were tested including AccI, AvaII (Boehringer Mannheim), AvaI, StyI (Sigma-Aldrich), BglI (Amersham, Life Science) and EaeI (Roche Applied Science), to distinguish the ND2 gene of 
all Tilapia species and their hybrids. One microlitre (10-12 units) was used for each digestion reaction, together with $1.2 \mu 1$ of the respective enzyme buffer for a final volume of $12.2 \mu \mathrm{l}$. The digestion was performed for $\sim 3.5 \mathrm{~h}$ at $\sim 37^{\circ} \mathrm{C}$, and the digestion products were evaluated on $2 \%$ TBE-agarose gels and stained with ethidium bromide. Bands were detected upon ultraviolet transillumination and photographed.

\section{Results}

Tilapia were identified by using morphometric and meristic analysis into four species and two hybrids. The genus Oreochromis included Oreochromis niloticus and Oreochromis aureus. The third species was Tilapia zillii and the fourth was Sarotherodon galilaeus. Another two individuals were identified as hybrids (H1 and H2). PCR-RFLPs tools were used in order to validate the evolution of mtND2 of these species taking into consideration the morphometric and meristic analysis. Total genomic DNA (nDNA and mtDNA) was extracted from liver of Tilapia species (T. zillii, O. niloticus, O. aureus, S. galilaeus and their hybrids) and represented in Figure 1; lanes 1-6 represented T. zillii, $O$. niloticus, O. aureus, S. galilaeus, $\mathrm{H} 1$ and H2 DNA genome, in that order. The sizes of the PCR products of the mtND2 gene were 1050 bp (Figure 2).

AccI restriction endonuclease digested mtND2 gene of $O$. auraeus uniquely into two restriction patterns $(\sim 100$ and $\sim 950 \mathrm{bp}$, lane 3; Figure 3 and Table 1) and did not react with the mtDN2 gene of the others and their hybrids (Figure 3 and Table 1). The mtDN2 gene of O. niloticus, $O$. aureus, $\mathrm{H} 1$ and $\mathrm{H} 2$ was digested with AvaI into two restriction fragments $(\sim 150$ and $\sim 900 \mathrm{bp}$, lanes 2-3 and 5-6; Figure 4 and Table 2), without digesting the same gene of $T$. zillii and $S$. galilaeus (lanes 1 and 4; Figure 4 and Table 2). The restriction enzyme, AvaII fragmented mtDN2 gene of $O$. aureus, $S$. galilaeus, $\mathrm{H} 1$ and $\mathrm{H} 2$ into same size of two restriction fragments ( 350 and $\sim 700 \mathrm{bp}$, lanes 3-6; Figure 5 and Table 3 ) whenever did not cut the mtDN2 gene of $T$. zillii and $O$. niloticus (lanes 1 and 2; Figure 5 and Table 3). $O$. niloticus, $O$. aureus and $\mathrm{H} 2$ of Tilapia species, their mtND2 gene cut into two bands $(\sim 150$ and $\sim 900 \mathrm{bp}$, lanes $2-3$ and 6 ; Figure 6 and Table 4) when treated with $B g$ II restriction endonuclease. The same restriction endonuclease undigested the genes of T. zillii, S. galilaeus and H1 (lanes 1 and 4-5; Figure 6 and Table 4) . EaeI restriction enzyme differentiated the mtDN2 gene of $T$. zillii and S. galilaeus when digesting this gene into two restriction fragments ( $\sim 0$ and $\sim 1000 \mathrm{bp}$, lanes 1 and 4; Figure 7and Table 5), whenever the same restriction endonuclease did not digest the same gene of the other species of Tilapia species (lanes 2-3 and 56; Figure 7and Table 5). StyI restriction endonuclease digested and identified the mtND2 gene of Tilapia species and their hybrids into three groups (Figure 8 and Table 6). The restriction endonuclease, StyI gathered $O$. niloticus, $\mathrm{H} 1$ and $\mathrm{H} 2$ in a group when digesting their mtND2 gene into three fragment patterns $(\sim 50, \sim 100$ and $\sim 900 \mathrm{bp}$, lanes 2 and 5-6), mtND2 of T. zillii and $O$. aureus in another group with two restriction fragments ( 50 and $\sim 1000 \mathrm{bp}$, lanes 1 and 3 ) while the same enzyme clustered the mtND2 of $S$. galilaeus in another different group with three different patterns ( 50, $\sim 400$ and $\sim 600$ bp, lane 4).

Table 1: Shows the length of mtND2 genes fragments, resulted from digestion with AccI enzyme in the six Tilapia species.

\begin{tabular}{|l|l|l|l|}
\hline Tilapia spp. & Band 1 & Band 2 & Band 3 \\
\hline T. zillii & $\sim 1050$ & ------ & ----- \\
\hline O. niloticus & $\sim 1050$ & ------ & ------ \\
\hline O. aureus & $\sim 100$ & $\sim 950$ & ------ \\
\hline S. galilaeus & $\sim 1050$ & ------ & ------ \\
\hline H1 & $\sim 1050$ & ------ & ------ \\
\hline H2 & $\sim 1050$ & ------ & ----- \\
\hline
\end{tabular}


Table 2: Shows the length of mtND2 genes fragments, resulted from digestion with AvaI enzyme in the six Tilapia species.

\begin{tabular}{|l|l|l|l|}
\hline Tilapia spp. & Band 1 & Band 2 & Band 3 \\
\hline T. zillii & $\sim 1050$ & ----- & ------ \\
\hline O. niloticus & $\sim 150$ & $\sim 900$ & ------ \\
\hline O. aureus & $\sim 150$ & $\sim 900$ & ------ \\
\hline S. galilaeus & $\sim 1050$ & ----- & ----- \\
\hline HI & $\sim 150$ & $\sim 900$ & ----- \\
\hline H2 & $\sim 150$ & $\sim 900$ & ------ \\
\hline
\end{tabular}

Table 3: Shows the length of mtND2 genes fragments, resulted from digestion with AvaII enzyme in the six Tilapia species.

\begin{tabular}{|l|l|l|l|}
\hline Tilapia spp. & Band 1 & Band 2 & Band 3 \\
\hline T. zillii & $\sim 1050$ & ----- & ------ \\
\hline O. niloticus & $\sim 1050$ & ----- & ----- \\
\hline O. aureus & $\sim 350$ & $\sim 700$ & ------ \\
\hline S. galilaeus & $\sim 350$ & $\sim 700$ & ----- \\
\hline H1 & $\sim 350$ & $\sim 700$ & ----- \\
\hline H2 & $\sim 350$ & $\sim 700$ & ------ \\
\hline
\end{tabular}

Table 4: Shows the length of mtND2 genes fragments, resulted from digestion with $\mathrm{Bg} 1 \mathrm{I}$ enzyme in the six Tilapia species.

\begin{tabular}{|l|l|l|l|}
\hline Tilapia spp. & Band 1 & Band 2 & Band 3 \\
\hline T. zillii & $\sim 1050$ & ----- & ------ \\
\hline O. niloticus & $\sim 150$ & $\sim 900$ & ------ \\
\hline O. aureus & $\sim 150$ & $\sim 900$ & ------ \\
\hline S. galilaeus & $\sim 1050$ & ----- & ----- \\
\hline H1 & $\sim 1050$ & ----- & ----- \\
\hline H2 & $\sim 150$ & $\sim 900$ & ------ \\
\hline
\end{tabular}

Table 5: Shows the length of mtND2 genes fragments, resulted from digestion with EaeI enzyme in the six Tilapia species.

\begin{tabular}{|l|l|l|l|}
\hline Tilapia spp. & Band 1 & Band 2 & Band 3 \\
\hline T. zillii & $\sim 50$ & $\sim 1000$ & ------ \\
\hline O. niloticus & $\sim 1050$ & ----- & ----- \\
\hline O. aureus & $\sim 1050$ & ----- & ----- \\
\hline S. galilaeus & $\sim 50$ & $\sim 1000$ & ----- \\
\hline HI & $\sim 1050$ & ----- & ----- \\
\hline H2 & $\sim 1050$ & ----- & ----- \\
\hline
\end{tabular}

Table 6: Shows the length of mtND2 genes fragments, resulted from digestion with StyI enzyme in the six Tilapia species.

\begin{tabular}{|l|l|l|l|}
\hline Tilapia spp. & Band 1 & Band 2 & Band 3 \\
\hline T. zillii & $\sim 50$ & $\sim 1000$ & ----- \\
\hline O. niloticus & $\sim 50$ & $\sim 100$ & $\sim 900$ \\
\hline O. aureus & $\sim 50$ & $\sim 1000$ & ----- \\
\hline S. galilaeus & $\sim 50$ & $\sim 400$ & $\sim 600$ \\
\hline H1 & $\sim 50$ & $\sim 100$ & $\sim 900$ \\
\hline H2 & $\sim 50$ & $\sim 100$ & $\sim 900$ \\
\hline
\end{tabular}



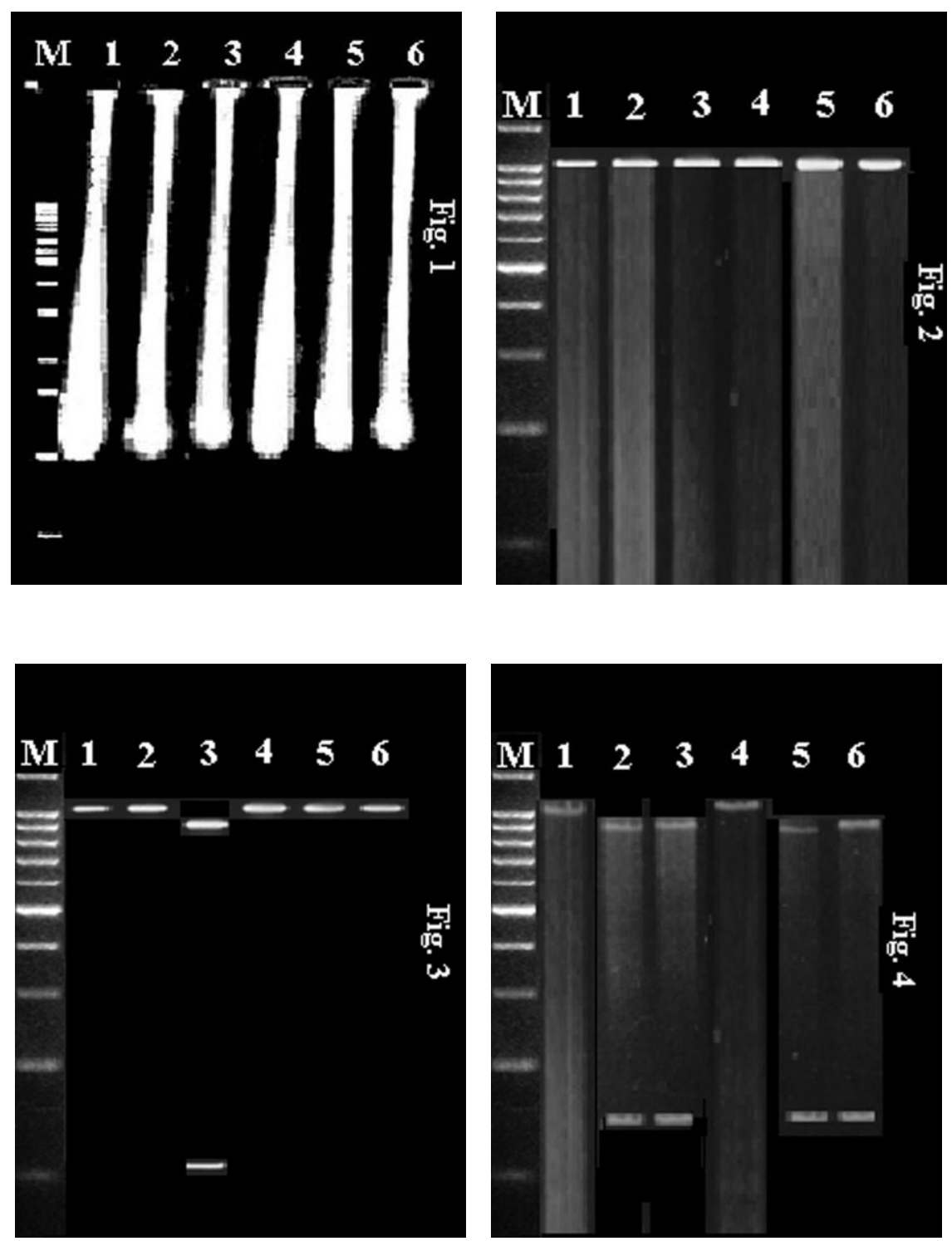

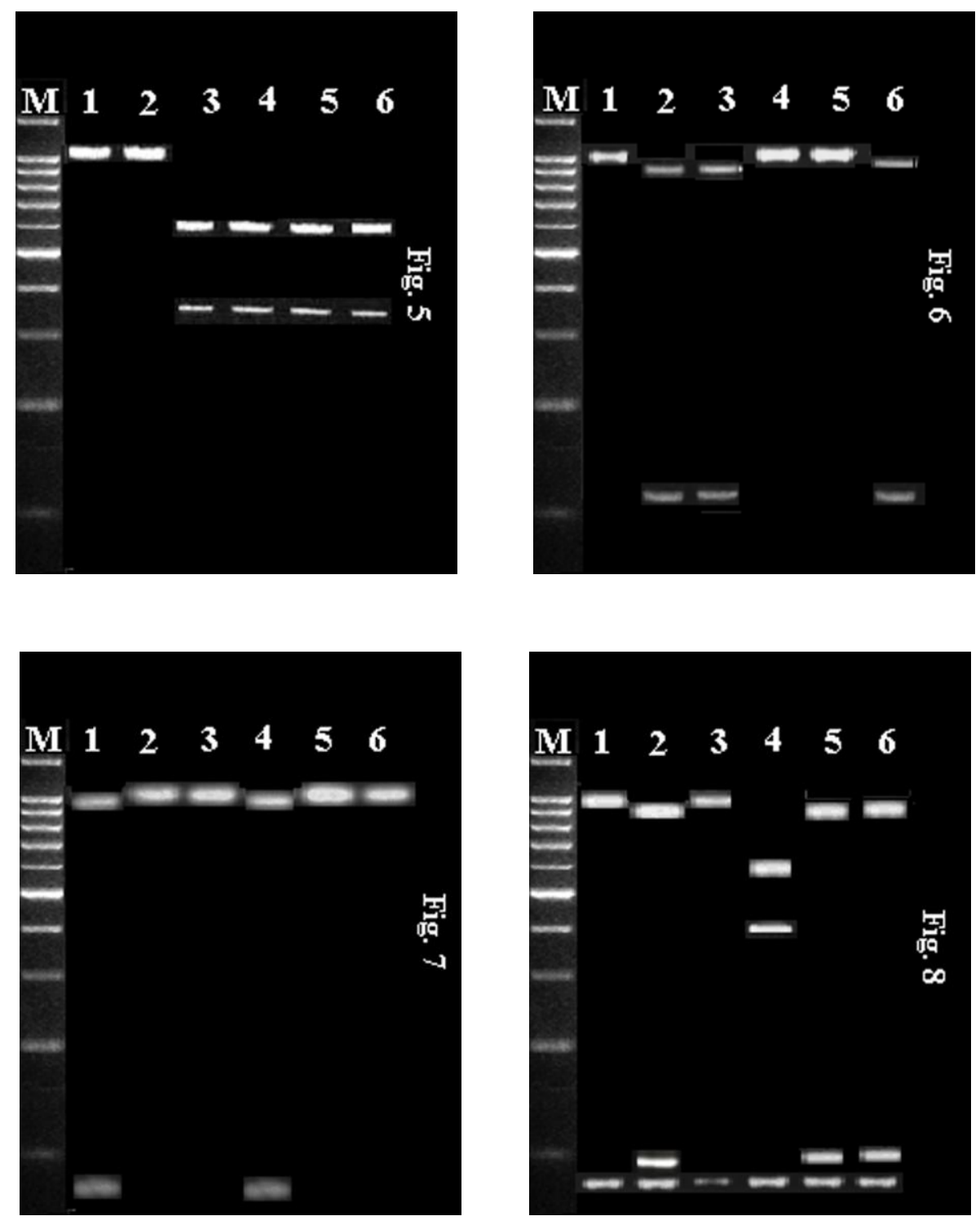
Figure 1: DNA genome from Tilapia spp.. Lane $\mathrm{M}$ is the $1 \mathrm{~kb}$ DNA ladder. Lanes $1-$ 6 represent the DNA genome of $T$. zillii, $O$. niloticus, O. auraeus, S. galilaeus, $\mathrm{H} 1$ and $\mathrm{H} 2$ respectively.

Figure 2: Symbolized full-segment mtND2 ( 1050 bp) of Tilapia spp.. Lane $\mathrm{M}$ is the 1 $\mathrm{kb}$ DNA ladder. Lanes $1-6$ represent srDNA of $T$. zillii, $O$. niloticus, $O$. aureus, $S$. galilaeus, $\mathrm{H} 1$ and $\mathrm{H} 2$ respectively.

Figure 3: shows AccI restriction enzyme digested the mtND2 of $O$. aureus uniquely into two different band sizes $(\sim 100$ and $\sim 950 \mathrm{bp}$, lane 3) whereas T. zillii, $O$. niloticus, $S$. galilaeus, $\mathrm{H} 1$ and $\mathrm{H} 2$ genes were not digested at all by this restriction enzyme (lanes 1, 2 and 4-6).

Figure 4: shows the representative RFLPs patterns from Tilapia spp. with AvaI restriction endonuclease, which produced roughly the same fragments (two bands) with $O$. niloticus, $O$. aureus, $\mathrm{H} 1$ and $\mathrm{H} 2$ ( 150 and $\sim 900 \mathrm{bp}$, lanes 2-3 and 5-6) whereas $T$. zillii and $S$. galilaeus genes were not digested at all by this restriction enzyme (lanes 1and 4).

Figure 5: shows AvaII restriction enzyme digested the mtND2 of $O$. aureus, $S$. galilaeus, $\mathrm{H} 1$ and $\mathrm{H} 2$ to two different band sizes ( $\sim 350$ and $\sim 700$ bp, lanes 3-6) whereas $T$. zillii and $O$. niloticus genes were not digested at all by this restriction enzyme (lanes 1and 2).

Figure 6: shows the representative RFLPs patterns from $O$. niloticus, $O$. aureus and H2 (two bands; 150 and $900 \mathrm{bp}$; lanes 2, 3 and 6); T. zillii, S. galilaeus and H1 were not digested at all (lanes 1, 4 and 5) with $B g$ II restriction endonuclease.

Figure 7: shows EaeI restriction enzyme digested the mtND2 of Tilapia zillii and S. galilaeus into two restriction fragments ( 50 and $\sim 1000 \mathrm{bp}$; lanes 1 and 4) whereas, O. niloticus, $O$. aureus, $\mathrm{H} 1$ and $\mathrm{H} 2 \mathrm{mtND} 2$ genes were not digested at all by this restriction enzyme (lanes 2, 3, 5 and 6).

Figure 8: shows StyI restriction enzyme digested the mtDN2 of $O$. niloticus, $S$. galilaeus, $\mathrm{H} 1$ and $\mathrm{H} 2$ to three different band sizes $(\sim 50, \sim 100$ and $\sim 900 \mathrm{bp}$, lanes 2 , 4, 5 and 6) whereas $T$. zillii and $O$. aureus
mtDN2 genes cut into two restriction patterns ( $~ 50$ and $\sim 1000 \mathrm{bp}$; lanes 1and 3).

\section{Discussion}

Differences in rates of evolution between and within mtND2 gene regions have important implications for phylogeny reconstruction and understanding the morphological, physiological, behavioral and ecological characteristics of the organisms specially Tilapia species (Fryer and Iles, 1972; Liem and Osse, 1975; Greenwood, 1978; Trewavas, 1983; Oliver, 1984; Meyer et al., 1990; Keenleyside, 1991; Meyer, 1993; Meyer et al., 1994 and Stiassny and Meyer, 1999).

These differences have been well documented for several gene regions (Holmquist et al., 1983; Li and Graur, 1991 and El-Serafy et al., in press). Ideally, differences in rates of evolution within and between gene regions would be reflected in phylogenetic weighting schemes by giving more weight to relatively conserved sites and substitution types which occur less frequently, thus emphasizing sites and changes with a lower probability of homoplasy.

Comparisons of the evolution of mitochondrial gene regions (Jacobs et al., 1988; Li and Graur, 1991; Mindell and Thacker, 1996 and Russo et al., 1996) suggest considerable variation in rates of change within and between gene regions. Comparisons of widely divergent taxa suggest differences in the rate and mode of evolution of NADH dehydrogenase subunit 2 (ND2) between the different species (Jacobs et al., 1988; Meyer, 1994 and Russo et al., 1996). It is important to determine whether or not these differences in constraints are evident at all taxonomic levels and whether these differences cause sequences of the mtND2 gene regions to be phylogenetically incongruent (Johnson and Sorenson, 1998).

Englander and Moav, 1989; Wright, 1989; Franck et al., 1992; Seyoum and Kornfield, 1992; Agnese et al., 1997; Rognon et al., 1996; Farias et al., 1999 and El-Serafy et al., (in press) used restriction fragment length polymorphisms of nuclear 
and mitochondrial DNA PCR products (RFLPsIPCR) as a basis for examining relationships among Tilapia spp. and finding out if the species is monophylogenetic or polyphylogenetic species and discovering specific enzymes to identify individual subspecies.

The present study clarified the evolution phylogeny of the NADH dehydrogenease gene (mtND2) of the Tilapia species in Egypt by using PCR/RFLPs technique. Uniquely, AccI restriction endonuclease differentiated mtND2 of the O. auraeus of the Tilapia species. Thus, mtND2 gene of $O$. auraeus is polyphylogenetic relationship when compared with the other species gene and differ than the others in the sequence. Also, mtND2 of O. niloticus, O. auraeus, $\mathrm{H} 1$ and $\mathrm{H} 2$ is evolutional phylogeneric difference with $T$. zillii and S. galilaus, when reacted with AvaI restriction enzyme. The evolution phylogeny of mtND2 of $O$. auraeus, S. galilaeus, $\mathrm{H} 1$ and $\mathrm{H} 2$ is different than the gene of $T$. zillii and $O$. niloticus when their gene fragmented with AvaII restriction enzyme. The ristriction endonuclease $B g l \mathrm{I}$ differentiated the mtND2 gene of Tilapia species into two groups ; O. niloticus, O. auraeus and $\mathrm{H} 2$ as a group and $T$. zillii, $S$. galilaeus and $\mathrm{H} 1$ as a group. While EaeI restriction enzyme differentiated the gene of $T$. zillii and $S$. galilaeus without cutting in the gene of the rest of Tilapia species gene. StyI restriction endonuclease clustered the mtND2 gene of Tilapia species, evolution phylogenetically, to three clusters when grouped the gene of $O$. niloticus, $\mathrm{H} 1$ and $\mathrm{H} 2$ in one group, the gene of $T$. zillii and $O$. auraeus in another and the mtND2 gene of $S$. galilaeus only in a separate group.

The PCR-RFLPs of NADH dehydrogenase gene of Tilapia species and their hybrids may prove that the gene is quite evolution phylogenetic difference from one species to another. At the same time, This study investigated the feasibility of mitochondrial DNA (mtDNA) based approaches in addressing problems of identification of Tilapia species and their hybrids, isolated from the River Nile by using the PCRRFLPs analysis of mtND2 gene.

\section{References}

1. Agnese, J.F.; Adepo-Gourene, B.; Abban, E.K.; and Fermon, Y. (1997). Genetic differentiation among natural populations of the Nile tilapia Oreochromis niloticus (Teleostei, cichlidae). Heredity. 79: 88-96.

2. Azab, M.S. (in press): Studies on some molecular biological aspects of Tilapia fish in Egypt. A thesis submitted in partial fulfillment of the requirements for the degree of the master degree of science in zoology. Faculty of Science - Zagazig University - Benha branch.

3. Danley, P.D.; Kocher, T.D. (2001) Speciation in rapidly diverging systems: lessons from Lake Malawi. Mol. Ecol. 10: 1075-1086.

4. El-Serafy, S.S.; Awwad, M.H.; Abd-ElHameid, N.H. and Azab, M.S. (in press) Using restriction fragment length polymorphisms (RFLPs) of the smallsubunit ribosomal DNA as a tool for identification of Tilapia spp.. (in press)

5. Englander, E. and Moav, B. (1989). Cloning and characterization of a histone gene family in Tilapia fish. Biochim Biophys Acta 1007, 277-82.

6. Farias, I.P.; Orti, G. and Meyer A. (2000). Total evidence: molecules, morphology, and the phylogenetics of cichlid fishes. J. Exp. Zool. 288: 76-92.

7. Farias, I.P.; Orti, G.; Sampaio, I.; Schneider, H. and Meyer, A. (1999). Mitochondrial DNA phylogeny of the family Cichlidae: monophyly and high genetic divergence of the Neotropical assemblage. J. Mol. Evol. 48(6) : 703-711.

8. Farias, I.P.; Orti, G.; Sampaio, I.; Schneider, H. and Meyer, A. (2001). The cytochrome $b$ gene as a phylogenetic marker: the limits of resolution for analyzing relationships among cichlid fishes. J. Mol. Evol. 53: 89-103.

9. Franck, J.P.; Wright, J.M. and McAndrew, B.J. (1992). Genetic variability in a family of satellite DNAs from tilapia (Pisces: Cichlidae). Genome, 35: 719-25.

10. Fryer, G. and Iles, T.D. (1972). The cichlid fishes of the Great Lakes of Africa-their biology and evolution. Oliver \& Boyd, Edinburgh; TFH Publications, Neptune City, New Jersey; 641 pp.

11. Goodwin, N.B.; Balshine-Earn, S. and Reynolds, J.D. (1998). Evolutionary transitions in parental care in cichlid fish. Proc. R. Soc. Lond. B 265: 2265-2272. 
12. Greenwood, P.H. (1978). A review of the pharyngeal apophysis and its significance in the classification of African cichlid fishes. Bull. Br. Mus. Nat. Hist. (Zool.). 33: 297-323.

13. Helfman, G.S.; Collette, B.B.; Facey, D.E. (1997) The diversity of fishes. Blackwell Science, Malden, Massachusetts. 507p.

14. Holmquist, R.; Goodman, M.; Conroy, T. and Czelusniak, J. (1983). The spatial distribution of fixed mutations within genes coding for proteins. J. Mol. Evol. 19: 437448.

15. Hugo, E.R.; Stewart, V.J.; Gast, R.J.; Byers, T.J. (1992). Purification of amoeba mtDNA using the UNSET procedure. In "Protocols in Protozoology," J.J. Lee \& A.T. Soldo, eds, Soc. Protozoologists, Lawrence, KA. pp D7.1-D7.2.

16. Jacobs, H.; Elliott, D.; Math, V. and Farquharson, A. (1988). Nucleotide sequence and gene organization of sea urchin mitochondrial DNA. J. Mol. Biol. 202: 185-217.

17. Johnson, K.P. and Sorenson, M.D. (1998). Comparing Molecular Evolution in Two Mitochondrial Protein Coding Genes (Cytochrome $b$ and ND2) in the Dabbling Ducks (Tribe: Anatini). Mol. Phylogen. Evol. 10: 82-94.

18. Keenleyside, M.H.A. (1991). Parental care. Pp. 191-208 in M.H.A. KEENLEYSIDE, ed. Cichlid fishes-behaviour, ecology and evolution. Chapman \& Hall, London.

19. Kocher, T.D.; Conroy, J.A.; Mckaye, K.R. and Stauffer, J.R.. (1993). Similar morphologies of cichlid fish in lakes Tanganyika and Malawi are due to convergence. Mol. Phylogenet. Evol. 2: 158-165.

20. Kocher, T.D.; Conroy, J.A.; Mckaye, K.R.; Stauffer, J.R.. and Lockwood, S.F. (1995). Evolution of NADH dehydrogenase subunit 2 in East African cichlid fish. Mol. Phylogenet. Evol. 4: 420-432.

21. Kocher, T.D.; Lee, W-J.; Sobolewska, H.; Penman, D.; McAndrew, B. (1998) A genetic linkage map of a cichlid fish, the Tilapia (Oreochromis niloticus). Genetics 148: 1225-1232.

22. Kullander, S.O. (1998). A phylogeny and classification of the South American Cichlidae (Teleostei: Perciformes). Pp. 461-498 in Malabarba, L. R.; Reis, R. E.; Vari, R. P.; Lucena, Z. M. and Lucena, C. A. S. eds. Phylogeny and classification of neotropical fishes. Part 5-Perciformes. Porto Alegre, Brazil.
23. Li, W-H., and Graur, D. (1991). "Fundamentals of Molecular Evolution," Sinauer, Sunderland, MA.

24. Liem, K.F. and Osse, J.W.M. (1975). Biological versatility, evolution, and food resource exploitation in African cichlid fishes. Am. Zool. 15: 427-454.

25. Meyer, A. (1993). Phylogenetic relationships and evolutionary processes in East African cichlids. Trends Ecol. Evol. 8: 279-284.

26. Meyer, A.; Kocher, T.D.; Basasibwaki, P. and Wilson, A.C. (1990) Monophyletic origin of Lake Victoria cichlid fishes suggested by mitochondrial DNA sequences. Nature. 347: 550-553.

27. Meyer, A.; Montero, C. and Spreinat, A.. (1994). Evolutionary history of the cichlid fish species of the East African great lakes inferred from molecular phylogenetic data. Arch. Hydrobiol. Beih. Ergebn. Limnol. 44:409-425.

28. Mindell, D.P. and Thacker, C.E. (1996). Rates of molecular evolution: phylogenetic issues and applications. Annu. Rev. Ecol. Syst. 27: 279-303.

29. Oliver, M.K. (1984). Systematics of African cichlid fishes: determination of the most primitive taxon, and studies on the haplochromines of Lake Malawi (Teleostei: Cichlidae). Yale University, Yale, Conn.

30. Pullin, R.S.V. and Lowe-Mcconnell, R.H. (1982). The biology and culture of Tilapias. ICLARM Conference Proceedings, Vol. 7. International Center for Living Aquatic Resources Management, Manila, Philippines.

31. Regan, C.T. (1920). The classification of the fishes of the family Cichlidae. I. The Tanganyika genera. Ann. Mag. Nat. Hist. 9:33-53.

32. Regan, C.T (1922). The classification of the fishes of the family Cichlidae. II. On African and Syrian genera not restricted to the Great Lakes. Ann. Mag. Nat. Hist. 9:249-264.

33. Rognon, X.; Andriamanga, M.; McAndrew, B. and Guyomard, R. (1996). Allozyme variation in natural and cultured populations in two Tilapia species: Oreochromis niloticus and Tilapia zilliii. Heredity, 76: 640-650.

34. Russo, C.M.; Takezaki, N. and Nei, M. (1996). Efficiencies of different gene and different tree-building methods in recovering a known vertebrate phylogeny. Mol. Biol. Evol. 13: 525-536. 
35. Schliewen, U.K.; Tautz, D. and BO, S.PA. A. (1994). Sympatric speciation suggested by monophyly of crater lake cichlids. Nature. 368:629-632.

36. Seyoum, S. and Kornfield, I. (1992). Identification of the subspecies of Oreochromis niloticus (Pisces: Cichlidae) using restriction endonuclease analysis of mitochondrial DNA. Aquacult, 102:29-42.

37. Sodsuk, P. (1993). Molecular genetics and systematics of tilapiine cichlids using allozymes and molecular characters. Ph.D. thesis, University of Stirling.

38. Stiassny, M.L.J. (1991). Phylogenetic intrarelationships of the family Cichlidae: an overview. Pp. 1-35 in Keenleyside, M. H. A. ed. Cichlid fishes-behaviour, ecology and evolution. Chapman \& Hall, London.

39. Stiassny, M.L.J. and Meyer, A. (1999). Cichlids of the Rift Lakes. Sci. Am. 280: 44-49.

40. Streelman, J.T.; Zardoya, R.; Meyer, A. and Karl, S.A. (1998). Multilocus phylogeny of cichlid fishes (Pisces: Perciformes): evolutionary comparison of microsatellite and single-copy nuclear loci. Mol. Biol. Evol. 15: 798-808.
41. Sturmbauer, C.; Verheyen, E. and Meyer, A. (1994) Mitochondrial phylogeny of the Lamprologini, the major substrate spawning lineage of cichlid fishes from Lake Tanganyika in Eastern Africa. Mol. Biol. Evol. 11: 691-703.

42. Trewavas, E. (1982) Tilapias taxonomy specification, in: The Biology and culture Tilapias, R.S.V. Pullin and R.H. Lowe eds. McConell lnternational Center for Living Aquatic Resources Managment, Manila, Philippines. 3-14.

43. Trewavas, E. (1983) Tilapiine fishes of the genera Sarotherodon, Oreochromis and Danakilia. British Museum of Natural History, London, UK. 583 p.

44. Wright, J.M. (1989). Nucleotide sequence, genomic organization and evolution of a major repetitive DNA family in tilapia (Oreochromis mossambicus/hornorum). Nucleic Acids Res., 17: 5071-9.

45. Zardoye, R.; Vollmer, D.M.; Craddock, C.; Streelman, J.T.; Karl,S. and Meyer, A. (1996). Evolutionary conservation of microsatellite flanking regions and their use in resolving the phylogeny of cichlid fishes (Pisces: Perciformes). Proc. R. Soc. Lond. B. 263:1589-1598. 


\section{العلاقات التطورية لجين إنزيم الناده ديهيروجينيز الخاص بالميتوكندريا في أسماك البلطى المصرى دئز النيز}

\section{محمد حسين عواد الزماد}

قسم علم الحيو ان - كلية العلوم - جامعة الزقازيق - فرع بنها

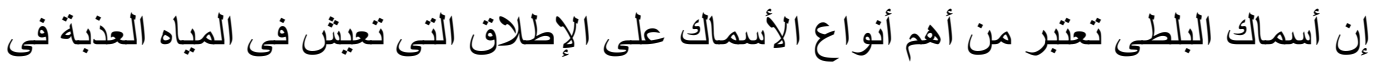

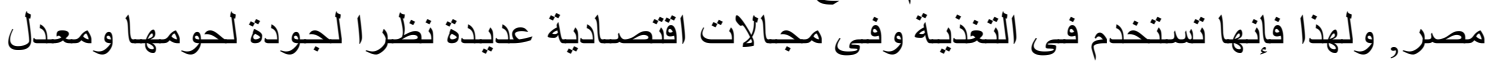

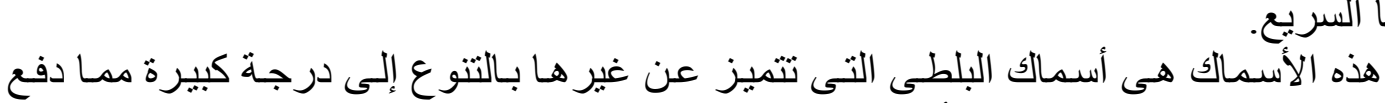

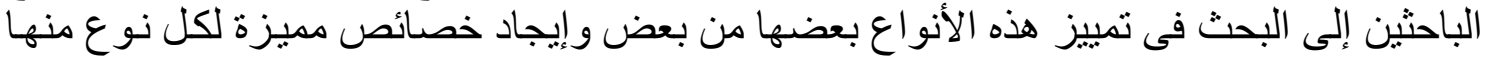

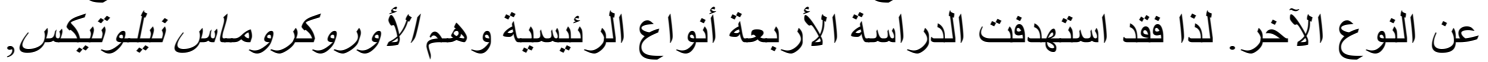

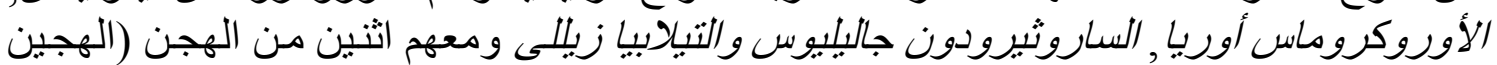

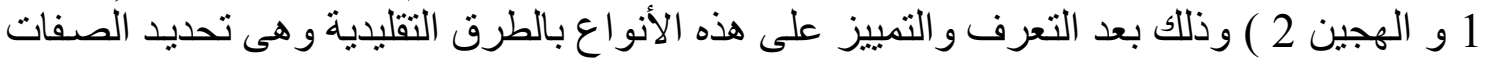
المورفو مترية والصفات الميريستمية. يهرف هذا البحث دراسة العلاقات التطوريـة للجين الذي ينتج إنزيم الناده ديهيدروجينيز

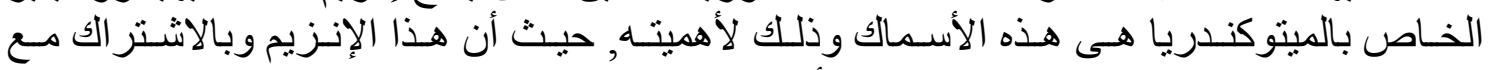

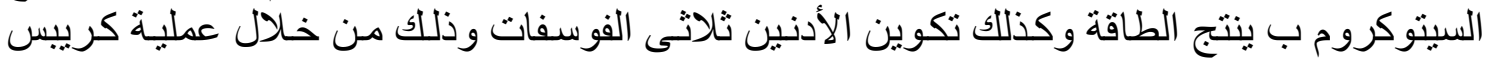

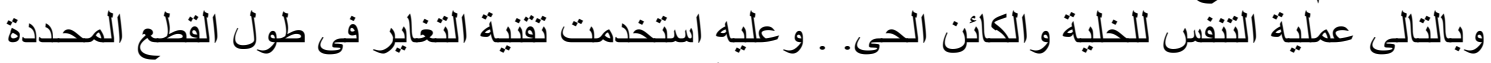

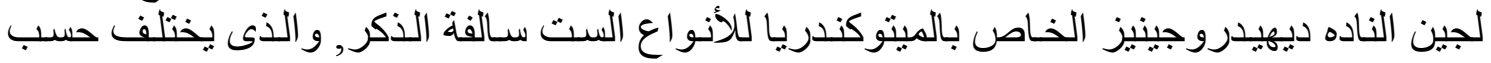
الطر از الذى ينتمى اليه الكائن الحى. الحي.

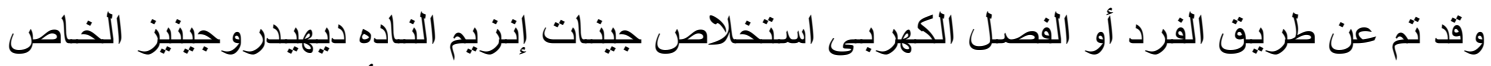

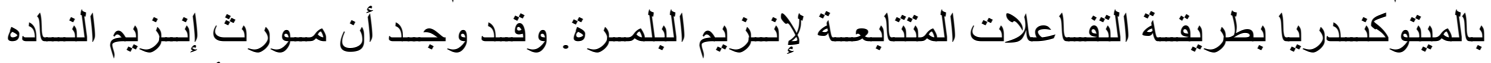

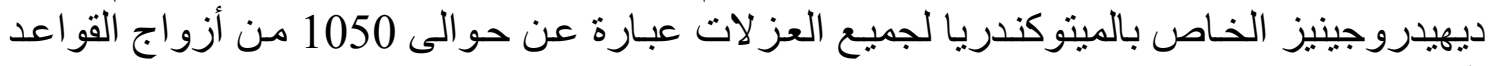
النيتروجينية. - النين. وقد وجد أنه عند هضم الجين بإنزيمى AccI أن سلالة جنس الأوروكروماس أوريا هى التى قد التد

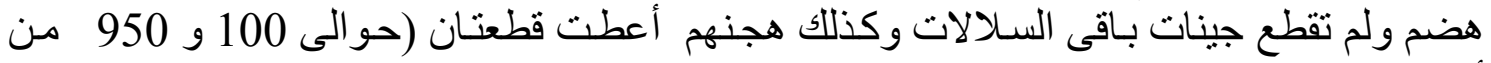

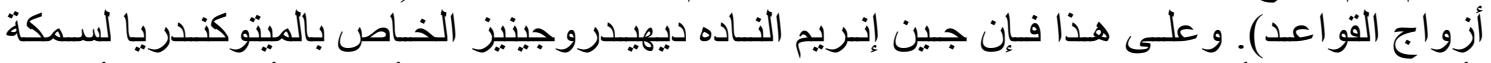

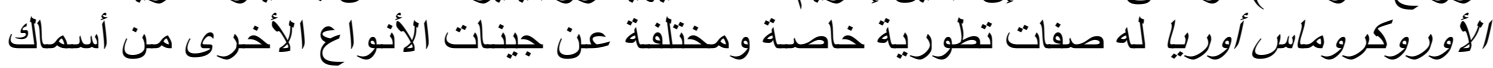

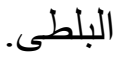
كذلك فإن جين إنريم الناده ديهيدروجينيز الخاص بالمينوكندريا لنوعى الساروثيرودون جاليليوس البيوس

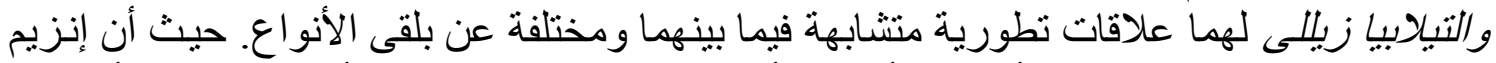

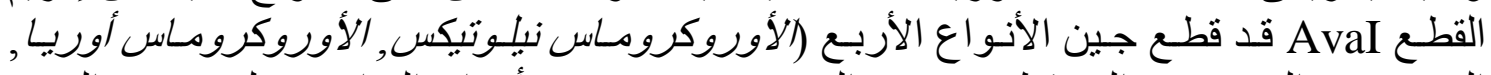

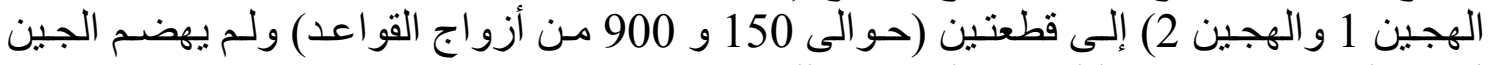
لنو عى الساروثيرودون جاليليوس والتيليانيبا زيليلى.

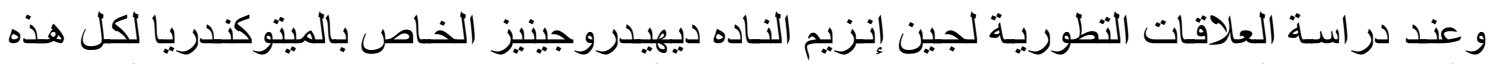

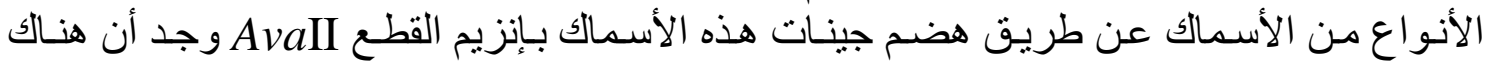

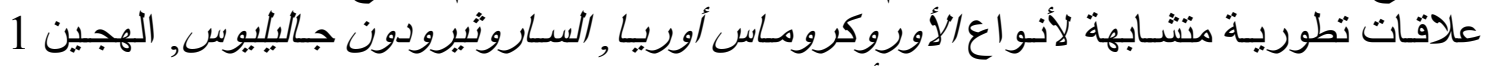

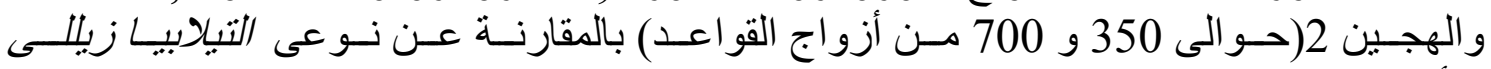

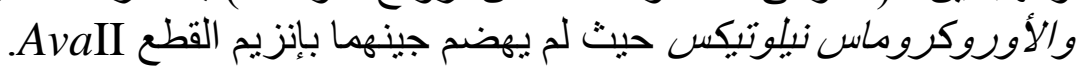


قد تبين أن هنالك علاقات تطورية متثابهة بين جين إنزيم الناده ديهيدروجينيز الخاص بالمينوكندريا

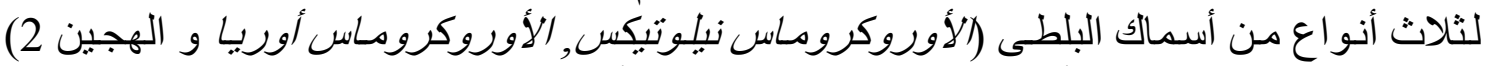

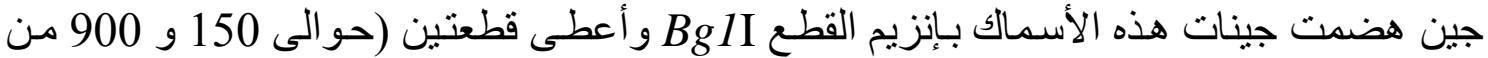

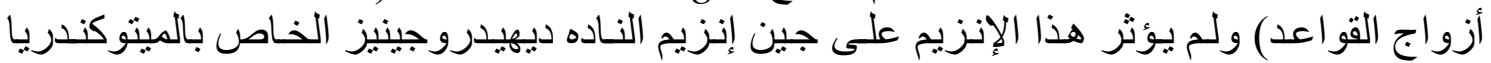

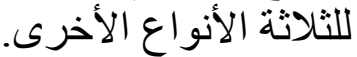

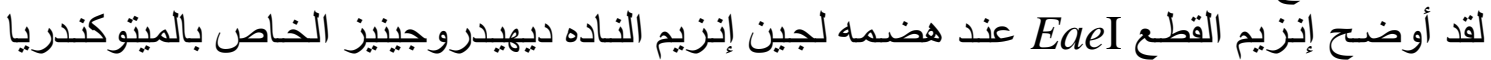

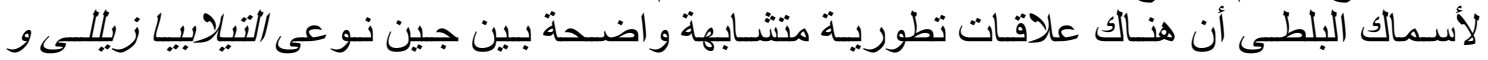

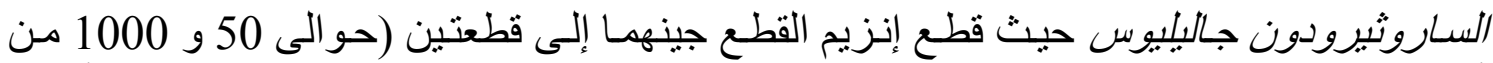

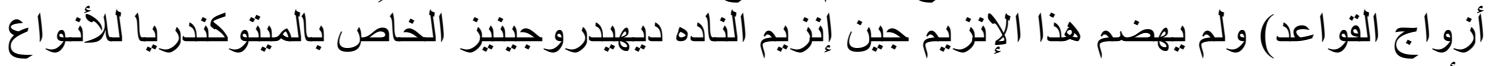

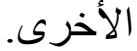

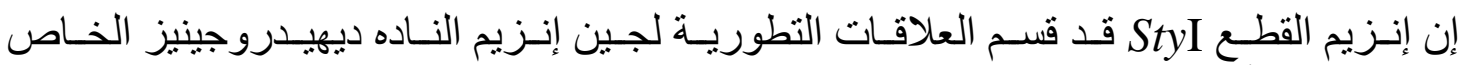

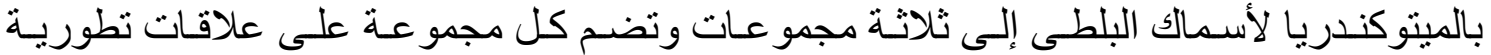

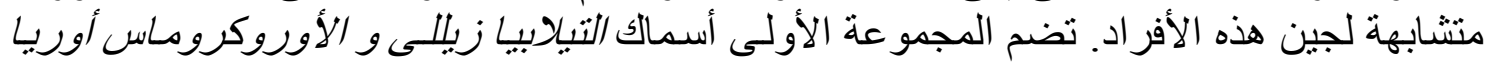

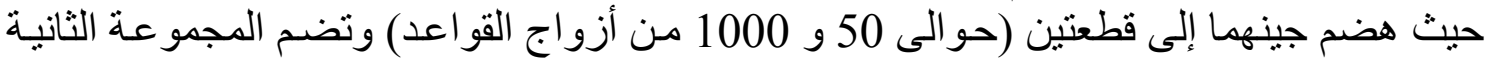

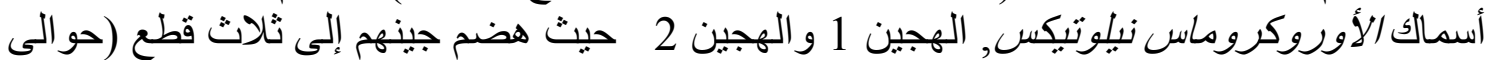

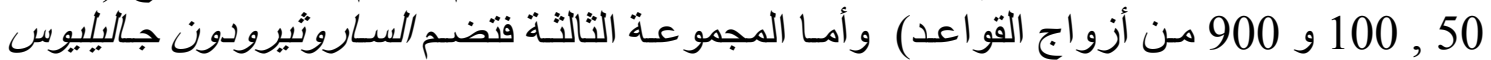

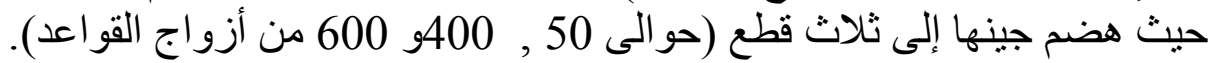

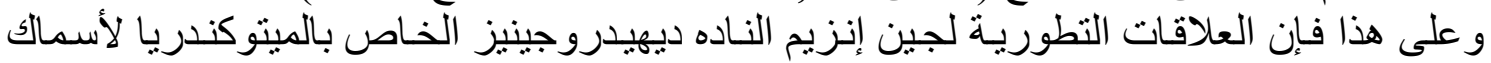

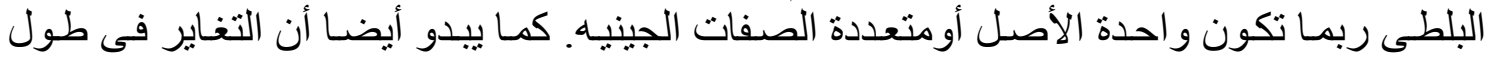

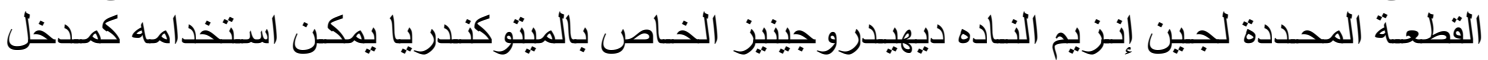
لللتعرف على الخصائص المعقدة لهذه الأسماك الك.

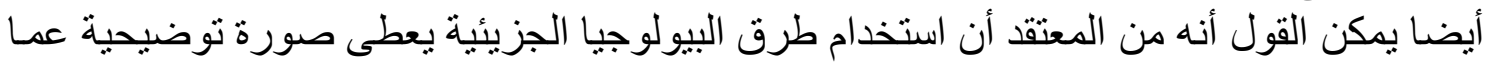

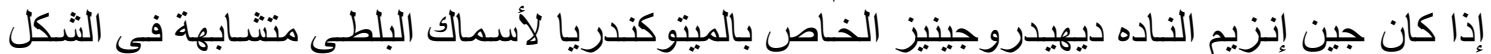

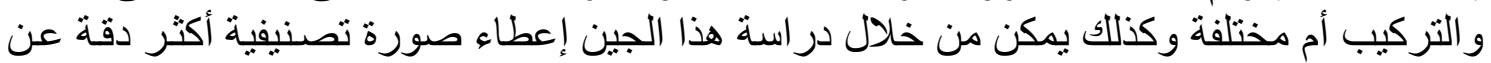
استخدام الثكل التركيبى فى هذه الدراسات. 